EWA DUDA

The Maria Grzegorzewska University, Poland

\title{
ACCESS TO HIGHER EDUCATION: THE ADULT LEARNERS’ PERSPECTIVE
}

\begin{abstract}
Issues concerning access to higher education are seen differently in various European education systems. In some of them, the paths leading to the desired college or university can be wide, in others difficult to reach or very bumpy. Learners of schools for adults represent a particular group vulnerable to difficulties in accessing higher education. For these learners, the accomplishment of the entrance examination requirements is not always equally achievable as for youth schools students. This paper presents the comparison of various approaches to the issue of access to higher education for adult learners in European countries. In particular, it indicates two systems of learners' skills evaluation, similar in way of organization but opposite in obtained results. The first one is Finnish and the second one Polish Matriculation Examination system, regarded as the Entrance Exams to university level education. Both systems are presented from the perspective of learners of schools for adults, mostly young people who have dropeed out of the youth system. The analyses take into account secondary data from examination sessions 2015-2018, provided by the Polish Central Examination Board and the Finnish Matriculation Examination Board. The main goal of this paper is to indicate the difficulties faced by learners of upper secondary schools for adults, especially in Poland. The difficulties causing that door to higher education are closed in front of these learners.
\end{abstract}

KEYWORDS: entrance exams, Matriculation examination, effectiveness of adult education, comparative research, access to higher education 


\section{INTRODUCTION}

Nowadays, the higher education is becoming a necessary stage in the education system. It contributes to the development of productivity and economic growth and advances skills required for modern economies to higher level. The third-level education cooperates with various employers in order to improve the quality of work and cope with technical or civilization rapid changes. Broadly defined knowledge leads to societal development, regardless of field of research, from humanities to science (OECD, 2017). The graduation of postsecondary education creates an opportunity to enter the labour market more easily. Strengthening links between tertiary education institutions and employers through the organisation of internships, assistance in finding a job, educating in job searching methods, providing functions supporting professional career causes the reduction of the mismatch between the profile of graduates and the requirements of the labour market (McGuinness, Whelan and Bergin, 2016; Cabus and Somers, 2018; Akomaning, 2019).

As the tertiary education is seen as a profit not only for individuals but also for the community, the efforts are being made to encourage more and more secondary school graduates to study at university or college. After years of transformation from an elite system to mass higher education, the pursuit of universal education, open access education is becoming increasingly widespread. An important role in increasing access to higher education is undoubtedly played by the rapid progress of information technology (Trow, 2000; Morgan and Carey, 2009; Moloney and Oakley, 2010).

The process of widening higher education access is regarded as the policy of support social justice, it helps to reduce inequalities between various social groups (Wilson et al. 2014; Sitek, 2015; Riddell, 2016) or secure the necessary skilled workforce as the need to activate the individual potential of every student (Graham and Shaffer, 2011; Király, and Géring, 2019). With a view to achieving the greater access to postsecondary education two strategies are being used. The first one is the moralization, as the responsibility of higher education institutions to attract students from underrepresented groups. The second is the rationalization, as the responsibility of tertiary education institutions to support student's learning process in order to take 
full advantage of its future participation in the labour market (Mergner, Leišytè and Bosse, 2019).

Widening access to higher education is also seen through the development of the non-public and private sectors as a consequence of increased demand for educational services. Public universities are often not capable to offer the learning opportunities for all applicants (Miroń and MakarewiczMarcinkiewicz, 2018). But even if students can be encouraged to make the decision to participate in postsecondary education, they have to meet certain entry conditions. However, the way of application differs significantly in various educational systems (individual countries or particular universities), from requirements that are not difficult to meet, to demands that are unattainable for some groups of learners. Milder criteria are applied in countries where recruitment process is based on applications submitted to the higher education institutions, e.g. United Kingdom, Sweden. This is mainly due to the fact that each university there is allowed to determine the admission requirements on the basis of its own internal rules. According to this system even if person has not graduated secondary school still has the possibility to enrol be admitted to university on the basis of entrance tests, access courses, relevant references or previous professional experiences.

Another method used to select candidates is the organisation of admission examinations directly by the university. Such a way of recruitment is tailored to the needs and preferences of individual faculties and does not require passing general upper secondary subjects not directly linked with curriculum of the study. That solution is used in Slovakia. However, the most common solution is to recruit students on the basis of examination leading to the Secondary Leaving Certificate. The examination is mostly organized centrally Abitur (Germany), Eindexamen (Netherlands) or Matriculation Examination, in many countries called Matura (Austria, Poland, Slovenia). Despite the similar name, meaning or function it performs, the organisation of individual matriculation examinations varies from country to country (EU, 2019). In the presented paper two systems will be analysed, Finnish and Polish. 


\section{STRUCTURE OF THE FINNISH MATRICULATION EXAMINATION}

The Finnish Matriculation Examination consists only written tests. During a maximum of three consecutive sessions (organised biannually, in autumn and in spring) the candidate needs to pass at least four exams. The candidate's mother tongue exam is obligatory for every student. The other three tests shall be chosen from the following subjects: the second national language, one foreign language, mathematics and one subject of humanities and natural sciences, where one of these tests is chosen at an advanced level (Ylioppilastutkintolautakunta, 2020).

The candidate chooses the compulsory tests at the time of the enrolment on the Matriculation Examination. The choice cannot be changed later without a convincing reason. During the examination period, the chosen tests may be taken by the candidate only once. In case of failure to pass the compulsory exam, the test may be retaken twice during the three subsequent examination sessions.

While Polish and Finnish solutions seem to be similar in terms of the way the Matriculation Examination is organised, the way they are evaluated is significantly different. The basic assumption for the assessment of the Finnish exams is the comparability of the grades as prerequisite for fair selection of candidates for universities. As candidates can take the exam in different examination sessions and it is practically not possible to prepare exams on exactly the same level of difficulty, the system of assessment should enable a fair comparison of the level of knowledge and skills of students taking exams in various years. This premise served as a basis for the allocation of grades to the respective scoring results. The table 1 shows an approximate distribution of the examination grades. The grade "Improbatur" means failed exam. 
Table 1.

Approximate distribution of Finnish Matriculation Tests Grades

\begin{tabular}{|c|c|c|}
\hline Abbreviation & Grade & Share of all grade \\
\hline L & Laudatur & $5 \%$ \\
\hline E & Eximia cum laude approbatur & $15 \%$ \\
\hline M & Magna cum laude approbatur & $20 \%$ \\
\hline C & Cum laude approbatur & $24 \%$ \\
\hline B & Lubenter approbatur & $20 \%$ \\
\hline A & Approbatur & $11 \%$ \\
\hline I & Improbatur & $5 \%$ \\
\hline
\end{tabular}

Source: https://www.ylioppilastutkinto.fi/en/assessment-and-certificates/assessment-of-the-examination

\section{STRUCTURE OF THE POLISH MATRICULATION EXAMINATION}

the Polish Matriculation Examination consists of written tests and oral exams. During one session (organised once per year, in May) the candidate needs to take six exams and pass at least five of them, those on a basic level. The Polish oral exam, one foreign language oral exam, written Polish and mathematics are obligatory for every student. The other written exam shall be chosen from the following subjects: Polish, foreign language, mathematics, biology, chemistry, philosophy, physics, geography, history, history of music, history of art, computer science, knowledge of society, where this test is chosen at an advanced level (CKE, 2020). Every student can choose more subjects on advanced level, in accordance with one's preferences or higher education institution requirements, however this choice does not affect the passing of the examination.

The candidate chooses the compulsory tests at the time of the enrolment on the Matriculation Examination (the beginning of the school year when examination takes place). The last term for changing the choice is beginning of February. During the examination period, the chosen tests may be taken by the candidate only once. In case of failure to pass one compulsory exam, it may be retaken during the re-session organised in August. In case of failure 
to pass more than one compulsory exam, they may be retaken during the five subsequent examination sessions.

Every exam is scored. To pass the exam the candidate needs to obtain at least $30 \%$ of the points from the examination in each compulsory subject (oral or written) and take the examination in a selected additional subject regardless of the score.

\section{Current study}

Although access to higher education has increased significantly, some social groups still remain underrepresented. In Poland, the graduates of adult schools represent such a group. To bear in mind the cognitive gap complementation, the article compares two matriculation examination systems, Polish and Finnish. Two examples of similar way of organization but different in results obtained by particular groups of learners: students from schools for youths and learners from schools for adults.

The study addresses the research question, to what extent do the evaluation methods affect the pass rate of matriculation exams in the two systems, Finnish and Polish? The topic and analysed data are very unique, as effectiveness of secondary adult education is still underrepresented in educational discourse.

The problem of inequality between educational system for youth and adults in numerous countries is still undervalued. Nowadays it takes on a new meaning as majority of learners of adult schools are young people who have dropped out of the youth system. It is very important to recognise the existing problem and start the new debate on how to solve a social problem concerning creation of the educational system fitted to the adult learners' needs. The main purpose of the study is to draw attention to a socially important issue and to induce decision makers ponder about improving the educational praxis.

The access to higher education issues have been raised in some studies dedicated to adult learning (Saar, Täht and Roosalu, 2014, McCall et al.,2020). They analysed paths leading to university in different European countries, without analyses of the required students' achievements. 
The Matriculation Examination as the high-stakes exam (Marchant and Paulson, 2005) serves several roles, among others selecting role. In many countries is used as the university entrance examination. Over the last few decades this examination has evaluated from an elite form into an exam accessible to a wide range of candidates. In Finland in the 1970s the passing rate was $30 \%$, nowadays it increased closer to $60 \%$, giving students a chance to start their tertiary studies (Kupiainen, Marjanen and Hautamäki, 2016). Despite the significant impact on further education and labour market position, compulsory leaving school exams are a positive predictor of dropping out of school (Shuster, 2012). In particular this problem affects adult learners, dividing time between studying and household, family, professional responsibilities (Marks, Turner and Osborne, 2003). The necessity of paid work, very often overtime work as a low-skilled person, left too little spare time for systematic learning, still precluding access to higher education (Bamber and Tett, 1999). Rarely does research address the impact of the assessment method on results of university entrance exams. Thus it seems important to undertake this problem.

\section{MeTHODOLOGY}

The quantitative research design was used throughout the study. The research is focused on the data collected through official request and using existing datasets with the aim to analyse the method of assessment and its results and to provide the persuasive assertion about existing educational inequalities. The research is based on the secondary data from the official database of Statistics Poland (statistics portal https://stat.gov.pl/en/) and Finnish Matriculation Examination Board (the website providing statistics https:// www.ylioppilastutkinto.fi/tietopalvelut/tilastot/tilastotaulukot). Additional analysis were taken on basis of matriculation examinations results provided by special request from the Central Examination Board (Polish board) and Matriculation Examination Board (Finnish board). As the low results of matriculation examination in Poland are mainly determined by low results in mathematics exams the analysis were made mainly in reference to this examination subject. 
As during each matriculation examination session is open to candidates who choose only single exam, are retaking failed exam, continue to take examinations, or are just taking whole examination session it is hard to analyse general data provided by Matriculation Examination Boards in terms of pass rate of the Matriculation examination. However, the important issue in that study is the real possibility to pass whole required exams, which opens the doors to university.

\section{Participants}

The study is based on data including results of all candidates who took the matriculation examination in years 2015 - 2018, both in Poland and in Finland. In relation to data confidentiality regulations, the records received from Finnish Matriculation Examination Board and Central Examination Board did not contain personal information, including gender information.

The analyses were carried out for each session individually and juxtaposition sessions in both countries, including cross-analyses between individual session - years. Due to the fact the greatest disproportions occur in relation to the mathematics exam, the more thorough analysis was conducted for the results of this exam. Table 2 presents the distribution of candidates taking mathematics matriculation exams during each session, in reference to their analysed results $(\mathrm{N}=999891)$. 
Table 2.

Distribution of Candidates by Session, Type of School and Country

\begin{tabular}{|l|c|c|c|c|c|}
\hline \multirow{2}{*}{ Year } & \multicolumn{2}{|c|}{ Finnish Candidates } & \multicolumn{2}{c|}{ Polish Candidates } & \\
\cline { 2 - 6 } & $\begin{array}{c}\text { Adult } \\
\text { schools }\end{array}$ & All & Adult schools & All & Total \\
\hline 2015 Fall session & - & - & 3118 & 177666 & 177666 \\
\hline $\begin{array}{l}2015 \text { Autumn } \\
\text { session }\end{array}$ & 861 & 5548 & 0 & 0 & 5548 \\
\hline 2016 Fall session & 1124 & 11204 & 3429 & 261216 & 272420 \\
\hline $\begin{array}{l}2016 \text { Autumn } \\
\text { session }\end{array}$ & 702 & 4396 & 0 & 0 & 4396 \\
\hline 2017 Fall session & 973 & 11433 & 3814 & 261407 & 272840 \\
\hline $\begin{array}{l}2017 \text { Autumn } \\
\text { session }\end{array}$ & 619 & 4413 & 0 & 0 & 4413 \\
\hline 2018 Fall session & 918 & 11382 & 3101 & 251226 & 262608 \\
\hline Total & 5197 & 48376 & 13462 & 951515 & 999891 \\
\hline
\end{tabular}

Source: own elaboration based on obtained data

\section{RESULTS}

One of the significant differences in structure of matriculation examinations in both countries is the requirement to take the mathematics exam, not obligatory in Finland, obligatory in Poland. Even when mathematics is important in the process of university enrolment, not all Finnish passers decide to take maths exam. Despite the fact it is difficult to unequivocally state on the basis of published data which part of the candidates chooses the mathematics exam, it can be assumed that one fourth of them do not choose this subject at all (Table 3). 
Table 3.

\section{Registration for Matriculation Exams in Finland by Session and Subject}

\begin{tabular}{|c|c|c|c|}
\hline Year & $\begin{array}{c}\text { Mother tongue } \\
\text { (Finnish) }\end{array}$ & $\begin{array}{c}\text { Mathematics, basic } \\
\text { level }\end{array}$ & $\begin{array}{c}\text { Mathematics, ad- } \\
\text { vanced level }\end{array}$ \\
\hline 2015 Fall session & 27100 & 12519 & 10631 \\
\hline Autumn session & 5292 & 5986 & 1325 \\
\hline Total & 32392 & 18505 & 11956 \\
\hline 2016 Fall session & 27044 & 11663 & 10536 \\
\hline Autumn session & 4616 & 4745 & 1077 \\
\hline Total & 31660 & 16408 & 11613 \\
\hline 2017 Fall session & 26631 & 11898 & 1063 \\
\hline Autumn session & 4777 & 4837 & 11781 \\
\hline Total & 31408 & 16735 & 11716 \\
\hline 2018 Fall session & 27563 & 11934 & 1967 \\
\hline Autumn session & 4263 & 6511 & 13683 \\
\hline Total & 31826 & 18445 & 1063 \\
\hline
\end{tabular}

Source: own elaboration based on https://www.ylioppilastutkinto.fi/tietopalvelut/tilastot/tilastotaulukot

In some studies it can be found that one third of candidates do not choose mathematics (Hästö et all, 2019) on Matriculation Examination. This gives a chance to those who have problems with mathematics and want to continue their education in a profession which does not require strictly mathematical knowledge (although in fact its usefulness is indisputable). In Polish system if one is not able to learn mathematics at a certain level, in consequence the person is also unable to enter higher education. The ratio of passing matriculation exams indicates a large disproportion between the education system for youth and adults (see Table 4). While almost all youth students decide to take their matriculation exams $(M=95.3, S D=0.05)$, only every third adult school learner makes the corresponding decision $(M=30,2 ; S D=1,32)$. The data indicate also the disproportion in final results obtained by matriculates. For graduates of youth schools the pass rate is reasonably high $(\mathrm{M}=92.8$, $\mathrm{SD}=0.52)$, for graduates of adults schools corresponding pass rate is almost three times lower $(\mathrm{M}=31.4, \mathrm{SD}=1.93)$. The disproportion became larger for number of graduates who passed their matriculation exams with respect to 
all graduates, for matriculates from youth schools the average pass rate is then 88.4\% ( $\mathrm{SD}=0.49$ ), for matriculates from adults schools only 9.5\% ( $\mathrm{SD}=0.91$ ). Every tenth graduate of Polish adults schools can plan further education at university level. In particular for school year 2014/2015 the pass rate was only $8.4 \%$ with respect to all graduates.

Table 4.

Results of Matriculation Examination in General Upper Secondary Schools for Youth and Adults in Poland

\begin{tabular}{|c|c|c|c|c|c|c|}
\hline \multirow{3}{*}{$\begin{array}{c}\text { School year } \\
\text { a - schools for } \\
\text { youth } \\
\text { b- schools for } \\
\text { adults }\end{array}$} & \multicolumn{6}{|c|}{ Graduates } \\
\hline & \multirow[b]{2}{*}{ Total } & \multicolumn{2}{|c|}{$\begin{array}{l}\text { who have taken their } \\
\text { Matriculation Exams }\end{array}$} & \multicolumn{3}{|c|}{$\begin{array}{l}\text { who passed their } \\
\text { Matriculation Exams }\end{array}$} \\
\hline & & Total & $\begin{array}{c}\% \\
\text { In total }\end{array}$ & Total & $\begin{array}{c}\% \\
\text { In total }\end{array}$ & $\begin{array}{c}\% \\
\text { Pass rate }\end{array}$ \\
\hline $\begin{array}{r}2014 / 2015 \mathrm{a} \\
\mathrm{b}\end{array}$ & $\begin{array}{c}173253 \\
51600\end{array}$ & $\begin{array}{l}165136 \\
15221\end{array}$ & $\begin{array}{l}95.3 \\
29.5\end{array}$ & $\begin{array}{c}151971 \\
4358\end{array}$ & $\begin{array}{c}87.7 \\
8.4\end{array}$ & $\begin{array}{l}92.0 \\
28.6\end{array}$ \\
\hline $\begin{array}{r}2015 / 2016 \mathrm{a} \\
\mathrm{b}\end{array}$ & $\begin{array}{c}164129 \\
45888\end{array}$ & $\begin{array}{c}156657 \\
13266\end{array}$ & $\begin{array}{l}95.4 \\
28.9\end{array}$ & $\begin{array}{c}145377 \\
4221\end{array}$ & $\begin{array}{c}88.6 \\
9.2\end{array}$ & $\begin{array}{l}92.8 \\
31.8\end{array}$ \\
\hline $\begin{array}{r}2016 / 2017 \mathrm{a} \\
\mathrm{b}\end{array}$ & $\begin{array}{c}158303 \\
43490\end{array}$ & $\begin{array}{c}150887 \\
13297\end{array}$ & $\begin{array}{l}95.3 \\
30.6\end{array}$ & $\begin{array}{c}140451 \\
4318\end{array}$ & $\begin{array}{c}88.7 \\
9.9\end{array}$ & $\begin{array}{l}93.1 \\
32.5\end{array}$ \\
\hline $\begin{array}{r}2017 / 2018 \text { a } \\
\text { b }\end{array}$ & $\begin{array}{c}152419 \\
39891\end{array}$ & $\begin{array}{c}145315 \\
12707\end{array}$ & $\begin{array}{l}95.3 \\
31.9\end{array}$ & $\begin{array}{c}137295 \\
4170\end{array}$ & $\begin{array}{l}88.7 \\
10.5\end{array}$ & $\begin{array}{l}93.1 \\
32.8\end{array}$ \\
\hline
\end{tabular}

Source: own elaboration based on Główny Urząd Statystyczny, Oświata i wychowanie w roku szkolnym 2014/2015 - 2017/2018, Warsaw 2016-2019.

Comparing the results of exams in particular secondary school subjects, the greatest influence on the low pass rate has the mathematics exam. It is the main reason for the matriculation failure. The sources of low pass rate in mathematics, among other factors, can be considered in the examination papers assessment method. Every Polish mathematics examination sheet at basic level contains 34 tasks. There are 25 closed tasks (worth 1 point each) and 9 open tasks graded from 2 to 5 points. The candidate can gather 50 points in total, but needs to have at least 15 points to pass the exam (30\% of all points).

Every Finnish mathematics examination sheet at basic level contains three parts: A, B1 and B2. The candidate ought to complete 10 questions out of 13. Each question scores a maximum of six points. Part A consists of four 
questions, all of which are compulsory. Part B1 consists of five questions of which the candidate chooses three, and Part B2 consists of four questions of which the candidate again chooses three (https://www.ylioppilastutkinto.fi/ en/matriculation-examination/the-examination/description-of-tests). The candidate can gather 60 points in total, but needs to have at average 7 points to pass the exam (approximately $12 \%$ of all points).

Table 5 presents the analysis of distribution of points in matriculation session May 2018 in Poland and Spring 2018 in Finland. Due to the volume of the research data, only the results of one session are presented, however the rest of analysis of other sessions' results confirms the pattern. For the problem identification the results were compared according to the distribution used in the Finnish system. The score ranges for Polish candidates (presented in brackets) were determined according to the distribution for all matriculants. The employed Finnish evaluation method presents the number and percentage of students who did not pass the mathematics exam (the lowest line). One line above indicates Finnish students who passed the exam and Polish students who would pass the exam, but as they had not received at least $30 \%$ of all points, in reality they did not pass. As the grades in Polish matriculation examination do not depend on scores distribution, but on the predetermined scores, in consequence more candidates do not pass the exam. While in reference to students of youth schools from Finland and Poland we can say in some approximation examination results are similar (the ratio $17,8 \%$ is influenced by adult schools), for adult school learners the distribution is fundamentally different. When in Finland 10\% of candidates do not pass the mathematics exam, in Poland corresponding indicator is 7 times larger.

More importantly, it is worth to look at the problem as a whole. If we assume not all Finnish learners of adult schools choose mathematics exam, their passing rate of Matriculation Examination is slightly above $90 \%$. In Poland approximately $30 \%$ of learners of adult schools give up their Matura because of its difficulty and only $30 \%$ of learners who take the examination pass it, then the $90 \%$ of graduates do not pass the Matriculation Examination at all. The disparity between results in these two countries is enormous. 
Table 5.

Distribution of Points in Matriculation Examination, Session Fall 2018

\begin{tabular}{|c|c|c|c|c|c|c|}
\hline \multirow{2}{*}{$\begin{array}{c}\text { Finnish } \\
\text { Grade }\end{array}$} & & \multicolumn{3}{|c|}{ Finnish Candidates } & \multicolumn{2}{|c|}{ Polish Candidates } \\
\hline & & $\begin{array}{c}\text { Adult } \\
\text { Schools }\end{array}$ & $\begin{array}{c}\text { Youth } \\
\text { Schools }\end{array}$ & All & $\begin{array}{c}\text { Adult } \\
\text { schools }\end{array}$ & All \\
\hline $\mathrm{L}$ & $\mathrm{n}$ & 22 & 262 & 284 & 1 & 8137 \\
\hline \multirow[t]{2}{*}{9} & $\%$ & 2.4 & 2.5 & 2.5 & 0.0 & 3.2 \\
\hline & score & $<52 ; 59>$ & $<51 ; 59>$ & $<51 ; 59>$ & $<50 ; 50>$ & $<50 ; 50>$ \\
\hline E & $\mathrm{n}$ & 53 & 1043 & 1096 & 5 & 3722 \\
\hline \multirow[t]{2}{*}{8} & $\%$ & 5.8 & 10.0 & 9.6 & 0.2 & 9.4 \\
\hline & score & $<43 ; 51>$ & $<43 ; 51>$ & $<43 ; 51>$ & $<46 ; 49>$ & $<46 ; 49>$ \\
\hline M & $\mathrm{n}$ & 129 & 2122 & 2251 & 52 & 43561 \\
\hline \multirow[t]{2}{*}{7} & $\%$ & 14.1 & 20.3 & 19.8 & 1.7 & 17.3 \\
\hline & score & $<34 ; 43>$ & $<33 ; 43>$ & $<33 ; 43>$ & $<36 ; 45>$ & $<36 ; 45>$ \\
\hline $\mathrm{C}$ & $\mathrm{n}$ & 166 & 2656 & 2822 & 136 & 59201 \\
\hline \multirow[t]{2}{*}{6} & $\%$ & 18.1 & 25.4 & 24.8 & 4.4 & 23.6 \\
\hline & score & $<25 ; 33>$ & $<24 ; 33>$ & $<24 ; 33>$ & $<26 ; 35>$ & $<26 ; 35>$ \\
\hline $\mathrm{B}$ & $\mathrm{n}$ & 289 & 2840 & 3129 & 676 & 71893 \\
\hline \multirow[t]{2}{*}{5} & $\%$ & 31.5 & 27.1 & 27.5 & 21.8 & 28.7 \\
\hline & score & $<13 ; 24>$ & $<13 ; 24>$ & $<13 ; 24>$ & $<15 ; 25>$ & $<15 ; 25>$ \\
\hline A & $\mathrm{n}$ & 161 & 1145 & 1306 & 1135 & 30342 \\
\hline \multirow[t]{2}{*}{4} & $\%$ & 17.5 & 10.9 & 11.5 & 36.6 & 12.1 \\
\hline & score & $<7 ; 14>$ & $<8 ; 14>$ & $<7 ; 14>$ & $<9 ; 14>$ & $<9 ; 14>$ \\
\hline I & $\mathrm{n}$ & 98 & 396 & 494 & 1096 & 14370 \\
\hline \multirow[t]{2}{*}{$0-3$} & $\%$ & 10.7 & 3.8 & 4.3 & 35.3 & 5.7 \\
\hline & score & $<0 ; 8>$ & $<0 ; 8>$ & $<0 ; 8>$ & $<0 ; 8>$ & $<0 ; 8>$ \\
\hline \multicolumn{2}{|c|}{ Total } & 918 & 10464 & 11382 & 3101 & 251226 \\
\hline
\end{tabular}

Source: own elaboration based on analysed data 


\section{CONCLUSIONS}

The insurmountable barrier for Polish students of adult upper secondary schools is undoubtedly the compulsory passing of the mathematics exam on matriculation examination. It can be regarded from two perspectives. One is to see the matriculation examination as the selection factor. It selects not only a certain amount of knowledge and skills but as well the attributes of character: among others ability to pursue goals, diligence, systematic approach. But on the other hand every one of us is able to point out people who are really good professionals but very bad mathematicians. Is it fair enough to open only one gateway to the higher education, the same for everyone?

Second perspective is the assessment of quality of Polish adult secondary education. Is it really adapted to the needs of adult learners when so many of them are able to complete upper secondary school but at the same time are unable to pass the matriculation examination? The level of gained knowledge and skills during calls into question the effectiveness of education in schools for adults, as well as the adequacy of organisational solutions tailored to the real adult learners' needs. Presented results indicate Polish adult formal education urgently needs the help. The modifications are necessary. Maybe not the change of organization of matriculation examination, but certainly the reconstruction of learning/teaching process in secondary schools for adults. 


\section{REFERENCES}

Akomaning, E. (2019). Improving Student Internship Through Collaborative Curriculum Design: Needs and Context Analysis to Inform the Design Process. in: J. Pieters, J. Voogt and R.N. Pareja (eds.), Collaborative Curriculum Design for Sustainable Innovation and Teacher Learning. Springer, Cham, pp. 105-114.

Bamber, J., Tett, L. (1999). Opening the doors of higher education to working class adults: a case study. International Journal of Lifelong Education, 18(6), pp. 465-475. doi: $10.1080 / 026013799293522$.

Cabus, S. J., Somers, M. A. (2018). Mismatch between education and the labour market in The Netherlands: is it a reality or a myth? The employers' perspective. Studies in Higher Education, 43(11), pp. 1854-1867. doi:10.1080/03075079.2017.1284195.

Graham, J., Shaffer, D. (2011). Working Together on Widening Access, Admission and Transition into Higher Education. International Perspectives on Higher Education Research, 6, pp. 155-168.

Hästö, P., Palkki, R., Tuomela, D., Star, J. R. (2019). Relationship between mathematical flexibility and success in national examinations. European Journals of Science and Mathematics Education, 7(1), pp. 1-13.

Király, G., Géring, Z. (2019). Introduction to "Futures of Higher Education" Special Issue. Futures. doi:10.1016/j.futures.2019.03.004.

Kupiainen, S., Marjanen, J., Hautamäki, J. (2016). The problem posed by exam choice on the comparability of results in the Finnish matriculation examination. Journal for Educational Research Online, 8 (2), pp. 87-106.

Marchant, G. J., Paulson, S. E. (2005). The relationship of high school graduation exams to graduation rates and SAT scores. Education Policy Analysis Archives, 13(6). Retrieved 02 October 2019 from http://epaa.asu.edu/epaa/v13n6/.

McCall, D., Western, D., Petrakis, M. (2020). Opportunities for change: What factors influence non-traditional students to enrol in higher education? Australian Journal of Adult Learning, 60(1), pp. 89-112. doi:10.3316/ielapa.228794272705890.

McGuinness, S., Whelan, A., Bergin, A. (2016). Is There a Role for Higher Education Institutions in Improving the Quality of First Employment? The B.E. Journal of Economic Analysis \& Policy, 16 (4). doi:10.1515/bejeap-2016-0174.

Miroń, D., Makarewicz-Marcinkiewicz, A. (2018). Higher Education Market Formation in PostTransformation European Countries. Public and Non-Public Schools in the Higher Education Systems of Poland, the Czech Republic and Romania. Educational Studies Review, 27 (2), pp. 51-70. doi:10.12775/PBE.2018.016.

Mergner, J., Leišytè, L., Bosse, E. (2019). The Widening Participation Agenda in German Higher Education: Discourses and Legitimizing Strategies. Social Inclusion, 7 (1), pp. 61-70. doi:10.17645/si.v7il.1605.

Moloney, J. F., Oakley, B., II. (2010). Scaling Online Education: Increasing Access to Higher Education. Journal of Asynchronous Learning Networks, 14(1), pp. 55-70. 
Morgan, T., Carey, S. (2009). From Open Content to Open Course Models: Increasing Access and Enabling Global Participation in Higher Education. International Review of Research in Open and Distance Learning, 10(5).

OECD (2017). Benchmarking higher education system performance: Conceptual framework and data. Enhancing Higher Education System Performance. Paris: OECD.

Riddell, S. (2016). Widening Access to Scottish Higher Education: Unresolved Issues and Future Challenges. Scottish Educational Review, 48(1), pp. 3-12.

Saar, E., Täht, K., Roosalu, T. (2014). Institutional barriers for adults participation in higher education in thirteen European countries. Higher Education, 68(5), pp. 691-710. doi:10.1007/s10734-014-9739-8/.

Shuster, K. (2012). Re-Examining exit exams: New findings from the education longitudinal study of 2002. Education Policy Analysis Archives, 20(3), pp. 1-35.

Sitek, M. (2015). Roads and roadless tracts of European integration by university education. Journal of Modern Science, 3(26), pp. 151-163.

Trow, M. (2000). From Mass Higher Education to Universal Access: The American Advantage. Minerva, 37 (4), pp. 303-328.

Wilson, A., Hunter, K., Spohrer, K., Bruner, R., Beasley, A. (2014). Mentoring into higher education: A useful addition to the landscape of widening access to higher education? Scottish Educational Review, 46(2), pp. 18-35.

\section{NeTOGRAPHY}

CKE, https:/cke.gov.pl/egzamin-maturalny/egzamin-w-nowej-formule/o-egzaminie/, Retrieved on 02 October 2019.

Główny Urząd Statystyczny, Oświata i wychowanie w roku szkolnym 2015/2016, Zakład Wydawnictw Statystycznych, Warszawa 2017. https://stat.gov.pl/ obszary-tematyczne/edukacja/edukacja/oswiata-i-wychowanie-w-roku-szkolnym-20152016,1,11.html, Retrieved on 02 October 2019.

Główny Urząd Statystyczny, Oświata i wychowanie w roku szkolnym 2016/2017, Zakład Wydawnictw Statystycznych, Warszawa 2018. https://stat.gov.pl/obszary-tematyczne/ edukacja/edukacja/oswiata-i-wychowanie-w-roku-szkolnym-20162017,1,12.html, Retrieved on 02 October 2019.

Główny Urząd Statystyczny, Oświata i wychowanie w roku szkolnym 2017/2018, Zakład Wydawnictw Statystycznych, Warszawa 2019. https://stat.gov.pl/ obszary-tematyczne/edukacja/edukacja/oswiata-i-wychowanie-w-roku-szkolnym-20172018,1,13.html, Retrieved on 02 October 2019.

EU, https://europa.eu/youreurope/citizens/education/university/admission-entry-conditions/index_en.htm, Retrieved on 02 October 2019.

Ylioppilastutkintolautakunta, https://www.ylioppilastutkinto.fi/en/matriculation-examination/the-examination/structure-of-the-examination, Retrieved on 17 September 2019.

Ylioppilastutkintolautakunta, https://www.ylioppilastutkinto.fi/tietopalvelut/tilastot/ tilastotaulukot, Retrieved on 28 October 2019. 